\title{
Cytoplasmic and Nuclear Localizations Are Important for the Hypersensitive Response Conferred by Maize Autoactive Rp1-D21 Protein
}

\author{
Guan-Feng Wang ${ }^{1}$ and Peter J. Balint-Kurti ${ }^{1,2}$ \\ ${ }^{1}$ Dept. of Plant Pathology, North Carolina State University, Raleigh, NC 27695, U.S.A.; ${ }^{2}$ USDA-ARS Plant Science Research \\ Unit, Raleigh, NC 27695, U.S.A.
}

Submitted 14 January 2015. Accepted 4 May 2015.

\begin{abstract}
Disease resistance $(R)$ genes have been isolated from many plant species. Most encode nucleotide binding leucine-rich repeat (NLR) proteins that trigger a rapid localized programmed cell death called the hypersensitive response (HR) upon pathogen recognition. Despite their structural similarities, different NLR are distributed in a range of subcellular locations, and analogous domains play diverse functional roles. The autoactive maize NLR gene $R p 1-D 21$ derives from an intragenic recombination between two NLR genes, $R p 1-D$ and $R p 1-d p 2$, and confers a HR independent of the presence of a pathogen. Rp1-D21 and its N-terminal coiled coil (CC) domain $\left(C_{D 21}\right)$ confer autoactive $H R$ when transiently expressed in Nicotiana benthamiana. Rp1-D21 was predominantly localized in cytoplasm with a small amount in the nucleus, while $\mathrm{CC}_{\mathrm{D21}}$ was localized in both nucleus and cytoplasm. Targeting of $\mathrm{Rp1-D21}$ or $\mathrm{CC}_{\mathrm{D} 21}$ predominantly to either the nucleus or the cytoplasm abolished HR-inducing activity. Coexpression of $\mathrm{Rp1-D21}$ or $\mathrm{CC}_{\mathrm{D} 21}$ constructs confined, respectively, to the nucleus and cytoplasm did not rescue full activity, suggesting nucleocytoplasmic movement was important for HR induction. This work emphasizes the diverse structural and subcellular localization requirements for activity found among plant NLR $R$ genes.
\end{abstract}

To defend against pathogen infection, plants have evolved sophisticated, spatiotemporally finely tuned disease resistance mechanisms, one of which is mediated by resistance $(R)$ genes. Upon pathogen infection, $R$ gene products mediate the recognition of specific pathogen-derived molecules (effectors) and trigger a rapid localized programmed cell death, called the hypersensitive response (HR), at the point of pathogen ingress. $\mathrm{HR}$ is effective at restricting the growth and propagation of a wide variety of pathogens (Bent and Mackey 2007; Jones and Dangl 2006).

The products of most $R$ genes are nucleotide binding leucinerich repeat (NB-LRR or NLR) proteins, as they contain an $\mathrm{N}$-terminal domain followed by a central NB domain and C-terminal LRR domain (Caplan et al. 2008; Dangl and Jones

Corresponding authors: G.-F. Wang; E-mail: gwang11@ncsu.edu; P. Balint-Kurti; E-mail: peter.balint-kurti@ars.usda.gov

*The $\boldsymbol{e}$-Xtra logo stands for "electronic extra" and indicates that three supplementary figures and one supplementary table are published online.

(c) 2015 The American Phytopathological Society
2001; Takken and Tameling 2009). The N-terminal domains of these NLR proteins are generally one of two types: TNL proteins carry a toll-interleukin 1 receptor (TIR) domain at their N-terminus, while CNL proteins carry a coiled-coil (CC) domain (Cannon et al. 2002; Meyers et al. 1999).

The Rpl locus on maize chromosome 10 carries multiple tandemly repeated CNL-type $R$ gene paralogs, some of which confer resistance to specific races of maize common rust conferred by the fungus Puccinia sorghi (Hulbert 1997). The locus is meiotically unstable, due to a high frequency of unequal crossovers between paralogs (Sudupak et al. 1993). Unequal crossing over followed by intragenic recombination between two paralogs, $R p 1-D$ and $R p 1-d p 2$, resulted in the formation of the chimeric gene Rp1-D21 (Collins et al. 1999; Smith et al. 2010). In the Rp1-D21 protein, the recognition and elicitation functions are uncoupled, causing the spontaneous activation and formation of HR lesions on the leaves and stalks of the plant in the absence of pathogen recognition. Rp1-D21 has partially dominant gene action and its phenotypic effect is influenced by the environment, developmental stage, and genetic background (Chaikam et al. 2011; Chintamanani et al. 2010; Hu et al. 1996; Negeri et al. 2013; Smith et al. 2010).

While both the protein structures of and phenotypes conferred by NLR are generally conserved, the specifics of their function are surprisingly diverse, both at a molecular and subcellular localization level. Transient overexpression in Nicotiana benthamiana of different subdomains from different NLR can cause autoactive HR in the absence of pathogen infection. For example, transient expression of the $\mathrm{CC}$ domain of Arabidopsis ADR1, tobacco NRG1, and maize Rp1-D21 is sufficient to trigger HR (Collier et al. 2011; Wang et al. 2015). In contrast, transient expression of both the CC and CC-NB domains of barley MLA10 (Bai et al. 2012; Maekawa et al. 2011), the NB and CC-NB domains of potato Rx1 (Rairdan et al. 2008), and the CC-NB domain of Arabidopsis RPS5 (Qi et al. 2012) cause HR in $N$. benthamiana.

Similarly, different NLR function in different subcellular locations (Table 1). In different cases, either nuclear or cytoplasmic localization has been shown to be important for NLR functions in disease resistance and HR elicitation (Engelhardt et al. 2012; Hoser et al. 2013; Inoue et al. 2013; Qi et al. 2012; Slootweg et al. 2010; Wirthmueller et al. 2007; Zhu et al. 2010). In one case, it has been demonstrated that nuclear distribution of barley MLA10 is required for disease resistance to powdery mildew, while the cytoplasmic pool is required for HR (Bai et al. 2012), suggesting that, in this case, disease resistance and HR are dependent on separate processes. 
To investigate the subcellular localization requirement for Rp1-D21-induced HR, we manipulated the distribution of Rp1-D21 in nucleus and cytoplasm by adding nuclear localization signal (NLS) or nuclear export signal (NES) and found that both the cytoplasmic and nuclear localizations are required for Rp1-D21-induced HR. While it was demonstrated that the Potato virus $X$ NLR resistance protein $\mathrm{Rx}$ is likely activated in the cytoplasm and subsequently translocates to the nucleus to induce resistance (Slootweg et al. 2010; Tameling et al. 2010), to our knowledge, there are no other reports showing that both the cytoplasmic and nuclear distributions are required for HR induced by NLR.

\section{RESULTS}

Subcellular localization of Rp1-D21, Rp1-D, and Rp1-dp2.

We used Agrobacterium-mediated transient expression in $N$. benthamiana to investigate the function of Rp1-D21. We found that transient expression in N. benthamiana of Rp1-D21 but not of its two 'parental' alleles, Rp1-D and Rp1-dp2, confers a strong HR when the proteins were fused with a C-terminal eGFP (enhanced green fluorescent protein) (Fig. 1A), which is consistent with our previous report (Wang et al. 2015). The same HR phenotype was also reported when the proteins were fused to a C-terminal $3 \times \mathrm{HA}$ (hemagglutinin) tag or to no tag fusion (Wang et al. 2015).

Table 1. Summary of the current state of knowledge on the functional domains and subcellular localization of plant nucleotide binding leucine-rich repeats ${ }^{\mathrm{a}}$

\begin{tabular}{|c|c|c|c|c|c|c|c|}
\hline \multirow[b]{2}{*}{$\begin{array}{l}\text { Host } \\
\text { species/gene }\end{array}$} & \multirow[b]{2}{*}{ Pathogen } & \multirow[b]{2}{*}{$\begin{array}{l}\text { Protein } \\
\text { type }^{b}\end{array}$} & \multirow[b]{2}{*}{ Domain $^{c}$} & \multicolumn{3}{|c|}{ Subcellular localization } & \multirow[b]{2}{*}{ Reference } \\
\hline & & & & Of protein & $\begin{array}{l}\text { Required } \\
\text { for HR }\end{array}$ & $\begin{array}{c}\text { Required for } \\
\text { disease resistance }\end{array}$ & \\
\hline \multicolumn{8}{|l|}{ Arabidopsis } \\
\hline$A D R 1$ & - & $\mathrm{CNL}$ & $\mathrm{CC}$ & - & - & - & Collier et al. 2011 \\
\hline$R P M 1$ & $\begin{array}{l}\text { Pseudomonas } \\
\text { syringae }\end{array}$ & $\mathrm{CNL}$ & Full length & Plasma membrane & $\begin{array}{l}\text { Plasma } \\
\text { membrane }\end{array}$ & Plasma membrane & $\begin{array}{l}\text { Belkhadir et al. 2004; } \\
\text { Gao et al. } 2011\end{array}$ \\
\hline RPS2 & $\begin{array}{l}\text { Pseudomonas } \\
\text { syringae }\end{array}$ & $\mathrm{CNL}$ & $\begin{array}{l}\text { CC-NB, full } \\
\text { length }\end{array}$ & $\begin{array}{l}\text { Plasma membrane } \\
\text { and cytoplasm }\end{array}$ & - & - & $\begin{array}{l}\text { Axtell and Staskawicz } \\
\text { 2003; Day et al. 2005; } \\
\text { Tao et al. } 2000\end{array}$ \\
\hline RPS4 & $\begin{array}{l}\text { Pseudomonas } \\
\text { syringae }\end{array}$ & TNL & $\begin{array}{l}\text { TIR-NB-ARC, } \\
\text { TIR, full } \\
\text { length }\end{array}$ & Cytoplasm and nucleus & Nucleus & Nucleus & $\begin{array}{c}\text { García et al. 2010; Heidrich } \\
\text { et al. 2011; Williams et al. } \\
\text { 2014; Wirthmueller et al. } \\
\text { 2007; Zhang et al. } 2004\end{array}$ \\
\hline RPS5 & $\begin{array}{l}\text { Peronospora } \\
\text { parasitica }\end{array}$ & CNL & CC-NB & Plasma membrane & - & Plasma membrane & Qi et al. 2012 \\
\hline SNC1 & $\begin{array}{l}\text { Pseudomonas } \\
\text { syringae }\end{array}$ & TNL & - & Cytoplasm and nucleus & Nucleus & - & Zhu et al. 2010 \\
\hline \multicolumn{8}{|l|}{ Barley } \\
\hline MLA10 & $\begin{array}{l}\text { Blumeria } \\
\text { graminis }\end{array}$ & CNL & $\begin{array}{l}\text { CC, CC-NB, } \\
\text { CC-NB- } \\
\text { ARC, full } \\
\text { length }\end{array}$ & Cytoplasm and nucleus & Cytoplasm & Nucleus & $\begin{array}{l}\text { Bai et al. 2012; } \\
\quad \text { Maekawa, et al. } 2011\end{array}$ \\
\hline \multicolumn{8}{|l|}{ Flax } \\
\hline L6 & $\begin{array}{l}\text { Melampsora } \\
\quad \text { lini }\end{array}$ & TNL & TIR & Golgi & - & Golgi & $\begin{array}{l}\text { Bernoux et al. 2011; } \\
\text { Takemoto et al. } 2012\end{array}$ \\
\hline$M$ & $\begin{array}{l}\text { Melampsora } \\
\quad \text { lini }\end{array}$ & TNL & - & Tonoplast & - & - & Takemoto et al. 2012 \\
\hline \multicolumn{8}{|l|}{ Potato } \\
\hline$R x 1$ & Potato virus $X$ & $\mathrm{CNL}$ & $\begin{array}{l}\text { NB, CC-NB, } \\
\text { full length }\end{array}$ & Cytoplasm and nucleus & - & $\begin{array}{l}\text { Cytoplasm and } \\
\text { nucleus, } \\
\text { cytoplasm had } \\
\text { major role for } \\
\text { disease } \\
\text { resistance }\end{array}$ & $\begin{array}{l}\text { Rairdan et al. 2008; } \\
\text { Slootweg et al. 2010; } \\
\text { Tameling et al. } 2010\end{array}$ \\
\hline$R 3 a$ & $\begin{array}{l}\text { Phytophthora } \\
\text { infestans }\end{array}$ & $\mathrm{CNL}$ & - & $\begin{array}{l}\text { Cytoplasm in absence } \\
\text { of effector, endosome } \\
\text { in presence of effector }\end{array}$ & - & Endosome & Engelhardt et al. 2012 \\
\hline \multicolumn{8}{|l|}{ Maize } \\
\hline$R p 1-D$ & $\begin{array}{l}\text { Puccinia } \\
\text { sorghi }\end{array}$ & $\mathrm{CNL}$ & $\mathrm{CC}$ & - & - & - & Wang et al. 2015 \\
\hline$R p 1-d p 2$ & - & $\mathrm{CNL}$ & $\mathrm{CC}$ & $\begin{array}{l}\text { Cytoplasm and } \\
\text { membrane }\end{array}$ & - & - & $\begin{array}{l}\text { This study; Wang et al. } \\
2015\end{array}$ \\
\hline$R p 1-D 21$ & - & $\mathrm{CNL}$ & $\mathrm{CC}$, full length & $\begin{array}{l}\text { Cytoplasm, a small } \\
\text { amount in nucleus }\end{array}$ & $\begin{array}{l}\text { Cytoplasm } \\
\text { and nucleus }\end{array}$ & - & $\begin{array}{l}\text { This study; Wang et al. } \\
2015\end{array}$ \\
\hline \multicolumn{8}{|l|}{ N.tabacum } \\
\hline$N R G 1$ & - & $\mathrm{CNL}$ & $\mathrm{CC}$ & - & - & - & Collier et al. 2011 \\
\hline$N$ & $\begin{array}{l}\text { Tobacco } \\
\text { mosaic virus }\end{array}$ & TNL & - & Cytoplasm and nucleus & Nucleus & Nucleus & $\begin{array}{l}\text { Burch-Smith et al. 2007; } \\
\text { Hoser et al. 2013; Mestre } \\
\text { and Baulcombe } 2006\end{array}$ \\
\hline \multicolumn{8}{|r|}{ (1) - } \\
\hline $\mathrm{Pbl}$ & $\begin{array}{l}\text { Magnaporthe } \\
\text { oryzae }\end{array}$ & $\mathrm{CNL}$ & - & Cytoplasm and nucleus & - & Nucleus & Inoue et al. 2013 \\
\hline Pit & $\begin{array}{l}\text { Magnaporthe } \\
\text { oryzae }\end{array}$ & $\mathrm{CNL}$ & - & $\begin{array}{l}\text { Plasma membrane, } \\
\text { a small amount in } \\
\text { cytoplasm }\end{array}$ & $\begin{array}{l}\text { Plasma } \\
\text { membrane }\end{array}$ & Plasma membrane & $\begin{array}{l}\text { Kawano et al. 2010; } \\
\text { Kawano et al. } 2014\end{array}$ \\
\hline
\end{tabular}

\footnotetext{
a - indicates that no data are available.

${ }^{\mathrm{b}}$ CNL proteins carry a coiled-coil (CC) domain at their N-terminus, while TNL proteins carry a toll-interleukin 1 receptor (TIR) domain.

${ }^{c}$ Functional domain for autoactive hypersensitive response (HR). NB = nucleo binding.
} 


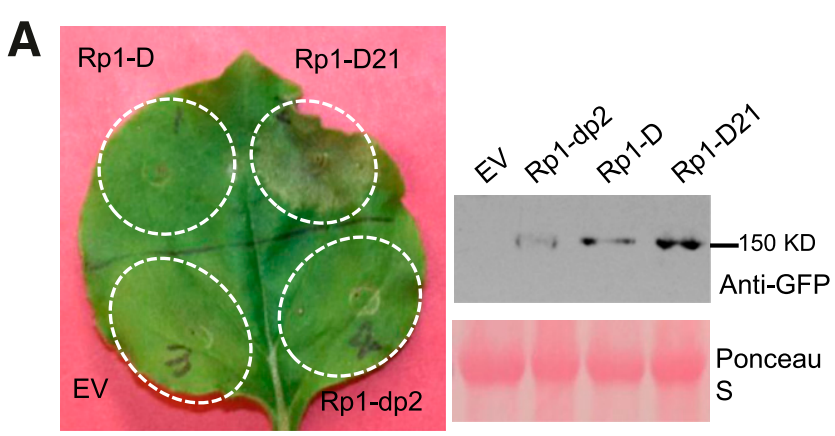

B
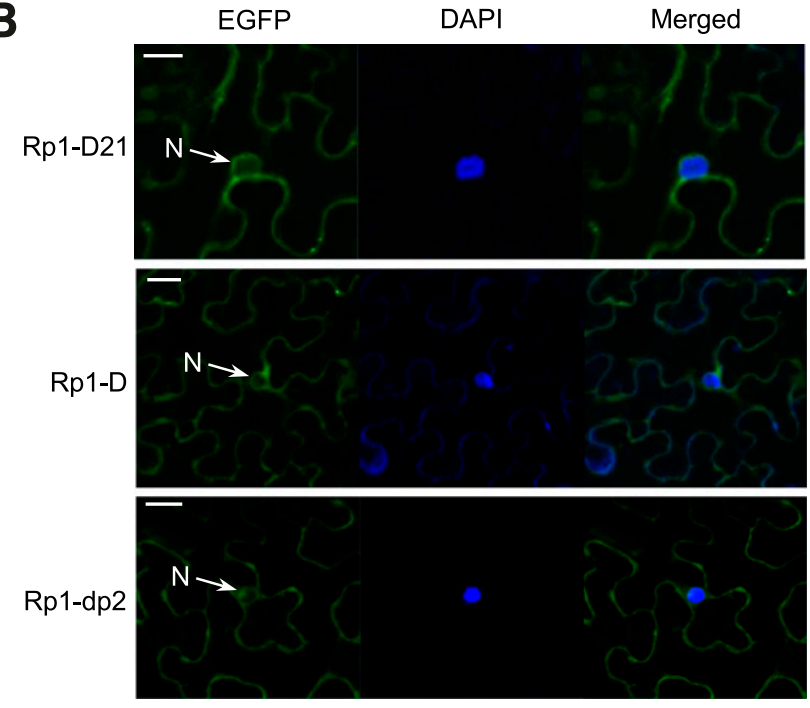

C

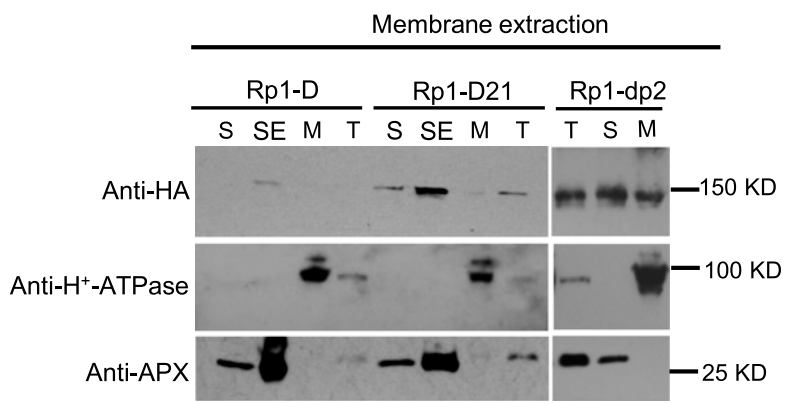

Fig. 1. The hypersensitive response phenotype conferred by Rp1-D21 and the subcellular localization of Rp1-D21, Rp1-D, and Rp1-dp2. The three proteins were fused with $\mathrm{C}$-terminal enhanced green fluorescent protein (eGFP) and were infiltrated into Nicotiana benthamiana. Experiments were repeated three times with the same results. A, Rp1-D21, Rp1-D, and Rp1dp2 proteins fused with a C-terminal eGFP tag were transiently expressed in $N$. benthamiana, with an empty vector (EV) as a negative control. A representative leaf was photographed at 3 days postinfiltration (dpi) (left). Total protein was extracted from agroinfiltrated leaves at $30 \mathrm{~h}$ postinfiltration (hpi), and anti-GFP antibody was used to detect the expression of the fused proteins (right). Equal loading of protein samples was shown by Ponceau S staining of the Rubisco subunit (below, right). B, From left to right, confocal images show the eGFP fluorescence, 4',6-diamidino-2phenylindole (DAPI) staining of the nucleus, and the merged fluorescence channels. The pictures were taken at $30 \mathrm{hpi}$ (Rp1-D21) or 48 hpi (Rp1-D and Rp1-dp2). The position of the nucleus (N) is indicated by arrows. The scale bars represent $20 \mu \mathrm{m}$. C, Rp1-D21, Rp1-D, and Rp1-dp2 were fused with a C-terminal $3 \times \mathrm{HA}$ (hemagglutinin) tag and were transiently expressed in $N$. benthamiana. Cells expressing these constructs were separated into soluble and membrane fractions. Anti- $\mathrm{H}^{+}$-ATPase and anti-APX (ascorbate peroxidase) antibodies were used as plasma membrane and cytoplasm markers, respectively. $\mathrm{S}=$ soluble; $\mathrm{SE}=$ soluble-enriched; $\mathrm{M}=$ membrane; and $\mathrm{T}=$ total.
To determine where in the cell Rp1-D21 functions to induce HR, Rp1-D21 fused with eGFP at the C-terminus, was transiently expressed in $N$. benthamiana and cells expressing the transgene were observed by confocal microscopy. Rp1-D21 was predominantly localized outside the nucleus, though we could not exclude the possibility that a small amount was present in the nucleus (Fig. 1B). We performed the same set of experiments with Rp1-D and Rp1-dp2 and did not observe obvious differences in the subcellular localizations between these proteins and those of Rp1-D21, using this method (Fig. 1B).

While confocal microscopy observations indicated that these three proteins were predominantly located outside the nucleus, this methodology did not allow us to differentiate cytoplasmic or membrane-associated localization. To determine whether the three proteins were membrane-associated, they were coexpressed with AtPLC2:CFP (cyan fluorescent protein), a plasma membrane (PM) marker (Gao et al. 2011; Hirayama et al. 1997). The eGFP fluorescence from Rp-D21 and Rp1-D did not colocalize with the CFP fluorescence (Supplementary Fig. 1), which suggested that Rp1-D21 and Rp1-D were not PM-associated proteins. The eGFP fluorescence from Rp1-dp2, however, did partially colocalize with the CFP signal, suggesting that Rp1-dp2 had PM distribution. To confirm these results, we performed fractionation of the membrane-associated and soluble components of the cell followed by Western blots. We found that, while Rp1-D21 was entirely localized in the soluble fraction (Fig. 1C), Rp1-dp2 was localized in both soluble and membrane fractions (Fig. 1C), confirming our AtPLC2:CFP colocalization results. Rp1-D was expressed at very low levels. It was detectable in the enriched soluble fraction, but we could not determine whether it had membrane localization in this experiment (Fig. 1C).

Subcellular localization of different domains of Rp1-D21.

Rp1-D21 consists of three different domains, namely, the $\mathrm{CC}, \mathrm{NB}$, and LRR domains (hereafter called $\mathrm{CC}_{\mathrm{D} 21}, \mathrm{NB}_{\mathrm{D} 21}$, and $\left.\mathrm{LRR}_{\mathrm{D} 21}\right)$. We showed that transient expression of $\mathrm{CC}_{\mathrm{D} 21}$ (amino acids [aa] 1 to 189 of Rp1-D21) is sufficient to induce HR when fused to eGFP, while no other domains or domain combinations induce HR when transiently expressed (Fig. 2) (Wang et al. 2015). To investigate whether the different HR phenotype was caused by different subcellular localization, we transiently expressed the different domains fused to eGFP in
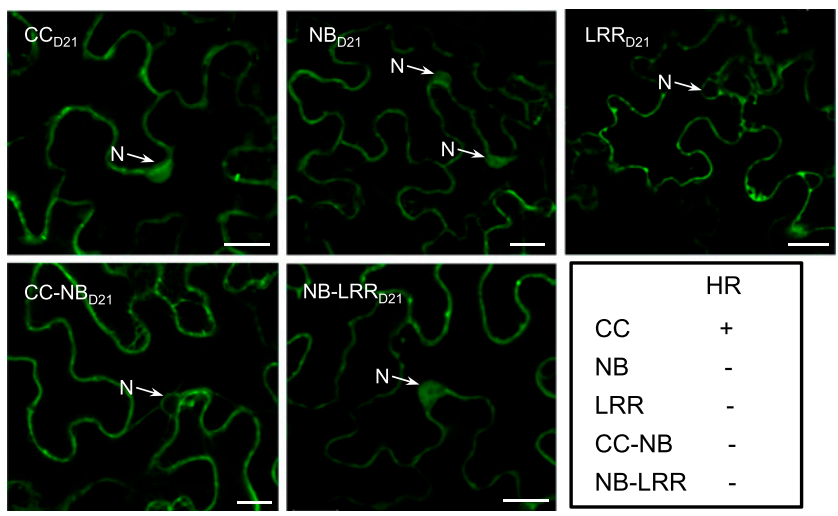

Fig. 2. The subcellular localization of different domains of Rp1-D21. The different domains $\left(\mathrm{CC}_{\mathrm{D} 21}, \mathrm{NB}_{\mathrm{D} 21}, \mathrm{LRR}_{\mathrm{D} 21}, \mathrm{CC}-\mathrm{NB}_{\mathrm{D} 21}\right.$, and NB-LRR $\left.\mathrm{D} 21_{1}\right)$ were fused with $\mathrm{C}$-terminal enhanced green fluorescent protein, and were infiltrated into Nicotiana benthamiana. Confocal images were taken at 30 $\left(\mathrm{CC}_{\mathrm{D} 21}\right)$ or $48 \mathrm{~h}$ postinfiltration $\left(\mathrm{NB}_{\mathrm{D} 21}, \mathrm{LRR}_{\mathrm{D} 21}, \mathrm{CC}-\mathrm{NB}_{\mathrm{D} 21}\right.$, and NB$\left.\mathrm{LRR}_{\mathrm{D} 21}\right)$. The position of the nucleus $(\mathrm{N})$ is indicated by arrows. The scale bars represent $20 \mu \mathrm{m}$. The abilities of constructs to induce (+) or not induce $(-)$ the hypersensitive response (HR) were indicated. The experiment was repeated three times with the same results. 
$N$. benthamiana and observed their subcellular localization patterns by confocal microscopy. $\mathrm{CC}_{\mathrm{D} 21}, \mathrm{NB}_{\mathrm{D} 21}$, and NB-LRR $\mathrm{D} 21_{1}$ had comparable levels of fluorescence in the cytoplasm and nucleus, while $\mathrm{LRR}_{\mathrm{D} 21}$ and $\mathrm{CC}-\mathrm{NB}_{\mathrm{D} 21}$ were predominantly localized in cytoplasm (Fig. 2).

\section{Both cytoplasmic and nuclear distributions are required for Rp1-D21- and $C_{D 21}$-mediated HR.}

The NLS motif is a short motif capable of directing proteins to the nucleus, while the NES motif directs the export of proteins out of the nucleus into the cytoplasm. The corresponding nls and nes motifs, in which a single aa or three aa, respectively, are mutated, have lost these functions (Bai et al. 2012; Shen et al. 2007; Wen et al. 1995). To investigate the subcellular localization requirements for Rp1-D21-mediated HR, NLS, and NES and their respective nonfunctional mutated versions, nls and nes were added to the C-terminus of Rp1-D21 and were fused to eGFP.

As expected, transiently-expressed Rp1-D21-NLS localized in the nucleus, while Rp1-D21-nls had an apparently similar localization pattern to Rp1-D21 (largely distributed in the cytoplasm) (Fig. 3A). Importantly, while Rp1-D21-nls triggered a slightly weaker HR than Rp1-D21, Rp1-D21-NLS did not induce HR at all (Fig. 3B). Rp1-D21-NES had similar apparent subcellular localization to Rp1-D21-nes and Rp1-D21 (Fig. 3A). However, while transient expression of Rp1-D21 and Rp1-D21nes triggered HR, Rp1-D21-NES did not. Ion leakage assays confirmed this result (Fig. 3C). The expression of all these constructs at the protein level was similar (Fig. 3D).

Essentially the same set of experiments were performed with $\mathrm{CC}_{\mathrm{D} 21}$, which was capable, on its own, of causing $\mathrm{HR}$ in $N$. benthamiana when fused to eGFP (Fig. 2). Confocal imaging showed that $\mathrm{CC}_{\mathrm{D} 21}$-NLS was predominantly localized in the nucleus and $\mathrm{CC}_{\mathrm{D} 21}$-NES in the cytoplasm (Supplementary Fig. 2). $\mathrm{CC}_{\mathrm{D} 21}$-nls and $\mathrm{CC}_{\mathrm{D} 21}$-nes, their respective counterparts with nonfunctional localization signals, were localized both in the cytoplasm and nucleus, similar to $\mathrm{CC}_{\mathrm{D} 21}$. Transient expression of $\mathrm{CC}_{\mathrm{D} 21}, \mathrm{CC}_{\mathrm{D} 21}$-nls, and $\mathrm{CC}_{\mathrm{D} 21}$-nes caused $\mathrm{HR}$, while $\mathrm{CC}_{\mathrm{D} 21}$-NLS and $\mathrm{CC}_{\mathrm{D} 21}$-NES did not confer a HR phenotype. Again, ion leakage assays confirmed this. All these constructs drove broadly equivalent levels of protein accumulation when transiently expressed. The lack of a 27-KDa band, indicative of free GFP, on the Western blot excluded the possibility that the nuclear fluorescence was caused by diffusion of free GFP (Rairdan and Moffett 2006). The results suggested that the cytoplasmic and nuclear distributions were required for the HR induced by Rp1-D21 (Table 1) and by its CC domain alone. Though it was difficult to visually discern the difference between the subcellular localizations of Rp1-D21-NES and Rp1-D21 (Fig. 3A), the predominant cytoplasmic localization of $\mathrm{CC}_{\mathrm{D} 21}$-NES compared with the nucleocytoplasmic distribution of $\mathrm{CC}_{\mathrm{D} 21}$ indicated that the NES functioned as expected to move protein out of nucleus.

\section{Protein shuttling between cytoplasm and nucleus is required for $\mathrm{Rp1-D21-}$ and $\mathrm{CC}_{\mathrm{D21}}$-triggered HR.}

Since neither the predominant distribution of Rp1-D21 and $\mathrm{CC}_{\mathrm{D} 21}$ in the cytoplasm or in the nucleus could induce HR (Fig. 3 ), we coexpressed $\mathrm{CC}_{\mathrm{D} 21}-\mathrm{NLS}$ and $\mathrm{CC}_{\mathrm{D} 21}$-NES in the same cell, with coexpression of $\mathrm{CC}_{\mathrm{D} 21}$-NLS and $\mathrm{CC}_{\mathrm{D} 21}$-nes as control. A strong eGFP signal was observed in both cytoplasm and nucleus in cells in which $\mathrm{CC}_{\mathrm{D} 21}$-NLS and $\mathrm{CC}_{\mathrm{D} 21}$-NES were coexpressed (Fig. 4A); however, the HR phenotype was greatly reduced compared with $\mathrm{CC}_{\mathrm{D} 21}$-nes or $\mathrm{CC}_{\mathrm{D} 21}$-nes $+\mathrm{CC}_{\mathrm{D} 21}$-NLS (Fig. 4B and C). Similar results were obtained when coexpression of Rp1-D21-NLS and Rp1-D21-NES, which produced much less or no HR compared with coexpression of Rp1-D21NLS and Rp1-D21-nes (Fig. 4). The data suggested that the HR induced by Rp1-D21 or $\mathrm{CC}_{\mathrm{D} 21}$ requires protein shuttling between cytoplasm and nucleus.
A

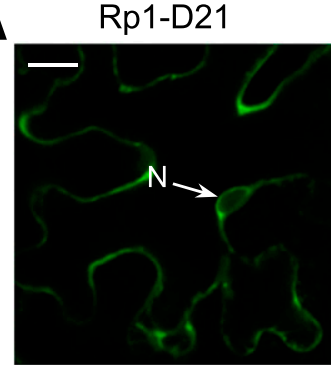

B

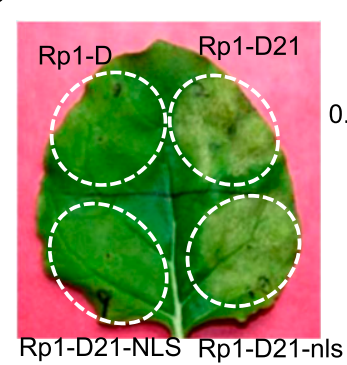

Rp1-D21-NLS
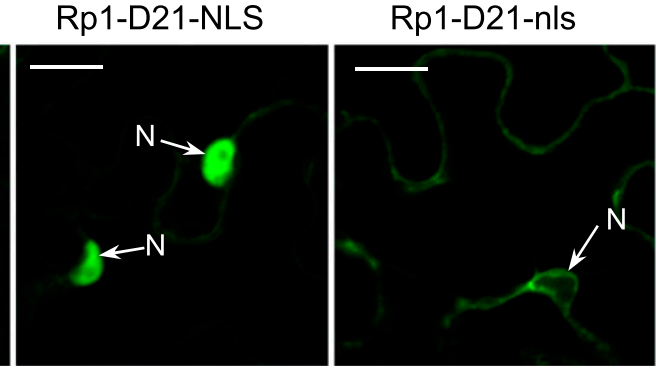

C

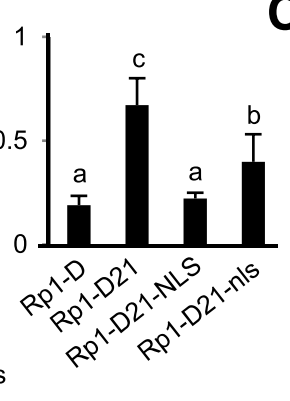

Rp1-D21-NES

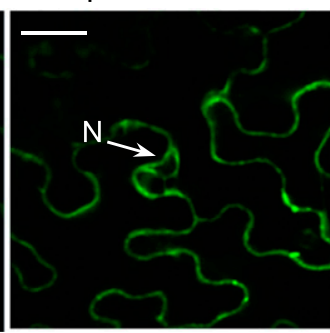

Rp1-D21-nes

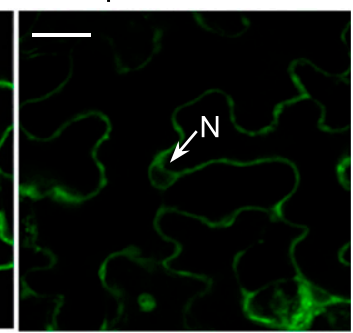

Fig. 3. Manipulation of the subcellular localization of Rp1-D21 and effects on Rp1-D21-triggered hypersensitive response (HR). A, Subcellular localization of Rp1-D21, Rp1-D21-NLS, Rp1-D21-nls, Rp1-D21-NES and Rp1-D21-nes. Proteins were fused to the N-terminal of enhanced green fluorescent protein and infiltrated into Nicotiana benthamiana. Confocal images were taken at $30 \mathrm{~h}$ postinfiltration (hpi). The nucleus (N) is indicated by arrows. The scale bar represents $20 \mu \mathrm{m}$. B and $\mathbf{C}$, HR phenotypes (left) and ion leakage conductivity (right) in $N$. benthamiana transiently expressing different fusion proteins as indicated. The pictures were taken at 3 days postinfiltration, and ion leakage conductivity ( \pm standard error) was measured at 62 hpi. Significant differences $(P<$ $0.05, n>5$ ) between samples are indicated by different letters. D, Total proteins were extracted from agroinfiltrated leaves at 30 hpi, and anti-GFP (green fluorescent protein) antibody was used to detect the expression of the fusion proteins (above). Equal loading of protein samples was shown by Ponceau $\mathrm{S}$ staining of Rubisco subunit (below). All experiments were repeated three times with the same results. 


\section{Precise structural requirement of the $\mathrm{CC}$ domain} for $\mathrm{HR}$ activation.

$\mathrm{CC}_{\mathrm{D} 21}$ (aa 1 to 189 ) causes HR when expressed transiently in $N$. benthamiana, while $\mathrm{CC}-\mathrm{NB}_{\mathrm{D} 21}$ (aa 1 to 527) does not (Wang et al. 2015). To investigate whether the different HR phenotypes caused by these constructs might be due to their different subcellular localizations, we generated a series of C-terminal deletion constructs fused to a C-terminal eGFP tag and transiently expressed them in $N$. benthamiana to determine their HR phenotypes and subcellular localizations (Fig. 5; Supplementary Fig. 3). $\mathrm{CC}_{\mathrm{D} 21}$ produced a strong $\mathrm{HR}$ (rating 4 on a 1 to 5 scale), while $\mathrm{CC}-\mathrm{NB}_{\mathrm{D} 21}$ did not induce $\mathrm{HR}$ (rating 0). The HR induced by $\mathrm{CC}_{\mathrm{D} 21}-160, \mathrm{CC}_{\mathrm{D} 21}-218$, and $\mathrm{CC}_{\mathrm{D} 21}-235$ was weak (rating 2), and no HR was observed in constructs $\mathrm{CC}_{\mathrm{D} 21^{-1}}-137$, $\mathrm{CC}_{\mathrm{D} 21}-260, \mathrm{CC}_{\mathrm{D} 21}-318$, and $\mathrm{CC}_{\mathrm{D} 21^{-}}-370$ (Fig. 5) (Wang et al. 2015). We also constructed $C_{C_{21}}-\Delta \mathrm{N} 20$ and $C_{D_{21}}-\Delta \mathrm{N} 10$, with 20- and 10-aa deletions from the $\mathrm{N}$ terminal of $\mathrm{CC}_{\mathrm{D} 21}$. Neither construct induced HR when transiently expressed in $N$. benthamiana (Fig. 5). Western blot results showed that all the constructs had high protein accumulation (Fig. 5C) (Wang et al. 2015). $\mathrm{CC}_{\mathrm{D} 21}-370$ (which did not confer HR) was predominantly localized in the cytoplasm, which is similar to
CC-NB-ARC $\mathrm{D}_{\mathrm{D} 21}$ (Fig. 2). However, all the other constructs (including both the $\mathrm{N}$-terminal and $\mathrm{C}$-terminal deletions with or without HR induction) had comparable fluorescence in both the nucleus and cytoplasm (Fig. 5A).

\section{DISCUSSION}

Differential subcellular localization patterns of Rp1-dp2, Rp1-D21, and subdomains.

Rp1-D21 and its 'parental' allele, Rp1-dp2, are more than $90 \%$ similar at the amino acid level (Wang et al. 2015). However, they have different subcellular localizations. Rp1-D21 was predominantly localized in cytoplasm, while Rp1-dp2 was localized in both cytoplasm and the plasma membrane (Fig. 1). The differences in subcellular localization between Rp1-dp2 and Rp1-D21 may, in part, be due to their different expression levels in the $N$. benthamiana transient expression system. Previously, we noted that Rp1-dp2 consistently had a higher expression level than Rp1-D21 when fused to a $3 \times \mathrm{HA}$ tag and transiently expressed in $N$. benthamiana (Wang et al. 2015).

Regarding the subdomains of Rp1-D21, $\mathrm{CC}_{\mathrm{D} 21}$ and $\mathrm{NB}_{\mathrm{D} 21}$ had comparable levels of fluorescence in cytoplasm and the
A

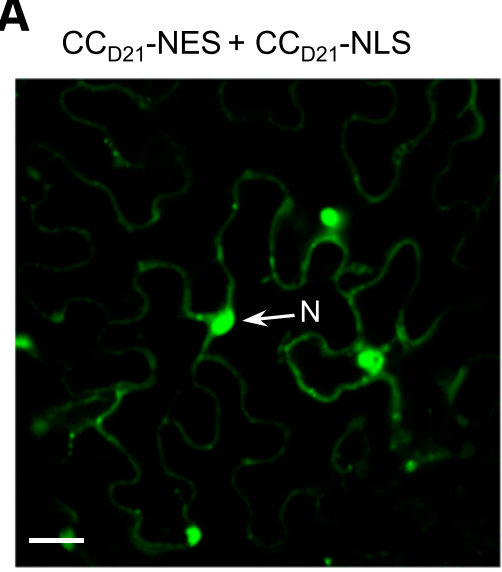

B
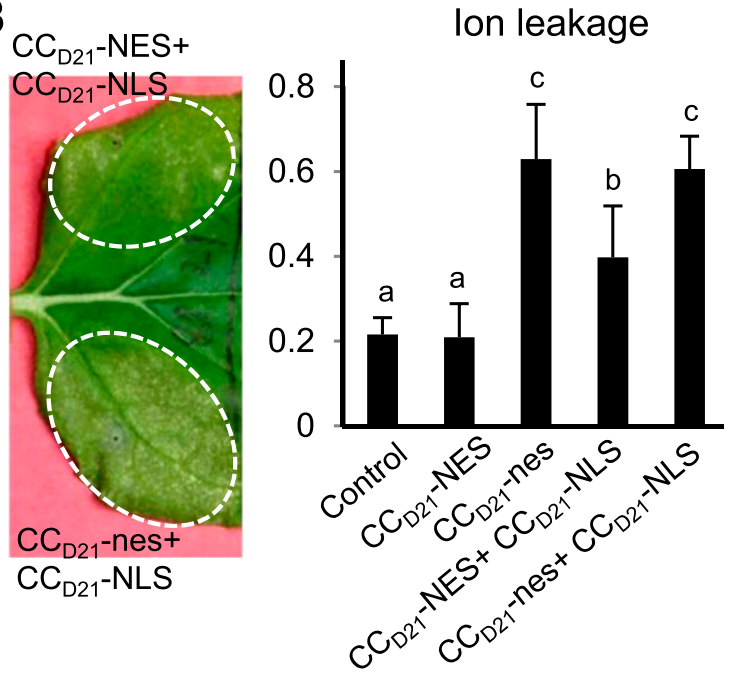

D

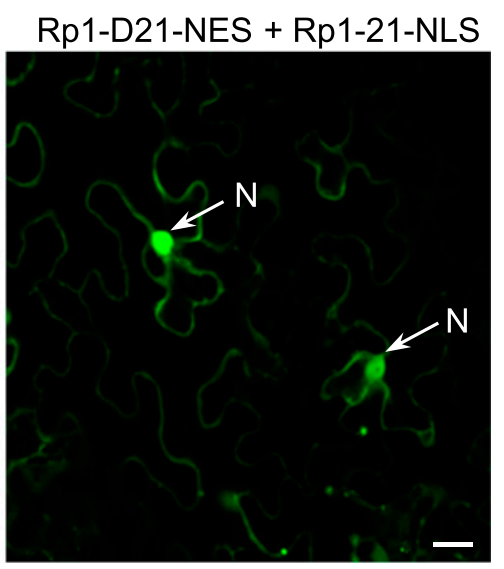

Rp1-D21-nes+

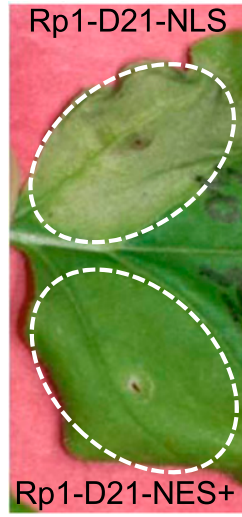

Rp1-D21-NLS

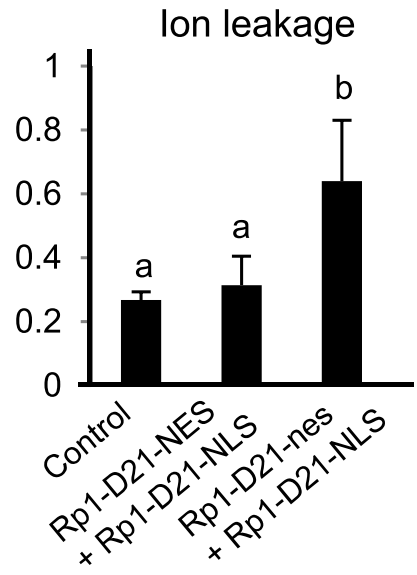

Fig. 4. Coexpression of $\mathrm{CC}_{\mathrm{D} 21}$ or Rp1-D21 in the nucleus and cytoplasm is not sufficient to induce the hypersensitive response (HR). A and $\mathbf{C}$, Subcellular localization of $\mathrm{CC}_{\mathrm{D} 21}-\mathrm{NES}+\mathrm{CC}_{\mathrm{D} 21}$-NLS (A) or Rp1-D21-NES + Rp1-D21-NLS (C). Constructs harboring the N-terminal enhanced green fluorescent protein tag were transiently expressed in Nicotiana benthamiana. The confocal image was taken at $30 \mathrm{~h}$ postinfiltration (hpi). $\mathrm{N}=$ nucleus, indicated by arrows. The scale bars represent $20 \mu \mathrm{m}$. B and D, HR phenotypes (left) and ion leakage conductivity (right) in $N$. benthamiana induced by the transient expression of different fusion proteins as indicated. The picture was taken at 3 days postinfiltration, and ion leakage conductivity ( \pm standard error) was measured at 62 hpi. Significant differences $(P<0.05, n>5)$ between samples are indicated by different letters. The experiments were repeated three times with similar results. 
nucleus, while the combination of the two, $\mathrm{CC}-\mathrm{NB}_{\mathrm{D} 21}$, was predominantly localized in cytoplasm (Fig. 2). This unexpected change in localization is likely caused by the interaction between the $\mathrm{CC}$ and $\mathrm{NB}$ domains and is consistent with our previous results showing that $\mathrm{NB}_{\mathrm{D} 21}$ can inhibit $\mathrm{CC}_{\mathrm{D} 21}$-induced HR (Wang et al. 2015). NB-LRR $\mathrm{D} 21_{1}$ was also localized in both cytoplasm and the nucleus (Fig. 2). Since full-length Rp1-D21 was predominantly localized in cytoplasm, we hypothesize that the interaction between $\mathrm{CC}_{\mathrm{D} 21}$ and $\mathrm{NB}-\mathrm{LRR}_{\mathrm{D} 21}$ somehow negates the function of potential NLS present on both domains. $\mathrm{CC}_{\mathrm{D} 21}, \mathrm{NB}_{\mathrm{D} 21}$, and NB-LRR $\mathrm{D} 21_{1}$ all localized in both cytoplasm and the nucleus; however, only $\mathrm{CC}_{\mathrm{D} 21}$ conferred $\mathrm{HR}$.

The $\mathrm{CC}_{\mathrm{D} 21}$ deletion construct experiments showed that transient expression of the conventionally defined CC motif, spanning from aa 1 to 189 , conferred the maximal level of $\mathrm{HR}$, suggesting that the entire domain was required for optimal activity. Even deleting just the first 10 aa, in which no known functional motif can be identified, abrogated autoactivity. In addition, extensions of the $\mathrm{CC}_{\mathrm{D} 21}$ domain such as $\mathrm{CC}_{\mathrm{D} 21}-235$ also showed reduced levels of activity, suggesting that aa beyond 189 had inhibitory effects on $\mathrm{CC}_{\mathrm{D} 21}$-induced $\mathrm{HR}$. All the constructs (including both the $\mathrm{N}$-terminal and $\mathrm{C}$-terminal deletions) had comparable fluorescence in both the nucleus and cytoplasm, with the exception of $\mathrm{CC}_{\mathrm{D} 21}-370$, which was predominantly localized in the cytoplasm. This suggests that differential HR phenotypes are not due to the differential subcellular localizations of different CC-derived deletion constructs.

\section{Subcellular localization requirements for HR induction.}

Given their similar structures and functions, it is surprising that different NLR appear to be localized in different subcellular compartments and that these different localizations are necessary for proper function. For instance, the tobacco N,
Arabidopsis RPS4, and SNC1 NLR localize in both the cytoplasm and nucleus and nuclear distribution is sufficient to induce HR (Burch-Smith et al. 2007; Hoser et al. 2013; Wirthmueller et al. 2007; Zhu et al. 2010). Pb1, encoded by a rice CNL gene, is localized in both the cytoplasm and nucleus and the nuclear localization is essential for blast resistance (Inoue et al. 2013). PM localization is required for RPM1-, RPS5- and Pit-mediated HR (Gao et al. 2011; Kawano et al. 2010, 2014; Qi et al. 2012). Potato R3a localizes in cytoplasm in the absence of its corresponding effector while in the endosome in the presence of its effector, and the endosomal localization is required for disease resistance (Engelhardt et al. 2012). Rx1, which confers extreme resistance to Potato virus $X$ (PVX), is located in the nucleus and cytoplasm and distribution over both compartments is required for disease resistance (Slootweg et al. 2010). Barley MLA10, a CNL protein, also localizes in both the cytoplasm and nucleus; nuclear distribution is required for disease resistance to powdery mildew, while the cytoplasmic pool is required for HR (Bai et al. 2012), suggesting that, in this case, disease resistance and HR are dependent on separate processes. Much of the literature on this field is summarized in Table 1. In this study, we found that Rp1-D21 and its HR-conferring subdomain $\mathrm{CC}_{\mathrm{D} 21}$ both localized in the cytoplasm and nucleus and that both nuclear and cytoplasmic distributions are required for conferring autoactive HR.

Previous studies have suggested the importance of nucleocytoplasmic shuttling in plant innate immunity through several different mechanisms, including mRNA export, NLS-dependent nuclear protein import, and NES-mediated nuclear protein export (Cheng et al. 2009; Palma et al. 2005; Tameling and Baulcombe 2007; Zhang and Li 2005). Nuclear localization may be required for the transcriptional reprogramming that has been shown to be important for the function of some NLR. Three NLR, i.e.,

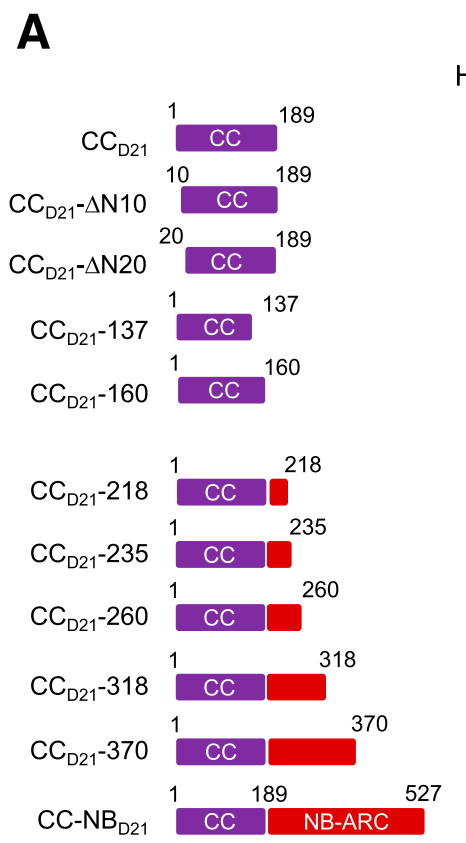

\begin{tabular}{ccc} 
& \multicolumn{2}{l}{ Subcellular localization } \\
\cline { 2 - 2 } & $\mathrm{N}$ & $\mathrm{C}$ \\
4 & + & + \\
0 & + & + \\
0 & + & + \\
0 & + & + \\
2 & + & + \\
2 & + & + \\
2 & + & + \\
0 & + & + \\
0 & + & + \\
0 & - & + \\
0 & - & +
\end{tabular}

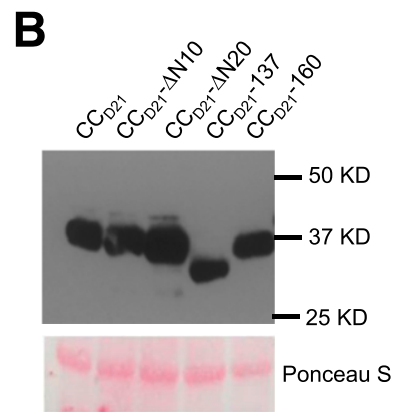

Fig. 5. Investigating the precise structural requirement of a series of $\mathrm{CC}_{\mathrm{D} 21}$-derived constructs fused with a $\mathrm{C}$-terminal enhanced green fluorescent protein to trigger the hypersensitive response (HR) when transiently expressed in Nicotiana benthamiana. A, Schematic diagram of a series of N- or C-terminal deletion constructs from the coiled coil (CC) and CC-NB (nucleo binding)-ARC domains and the results of transiently expressing them in $N$. benthamiana. The positions of the amino acids at which the deletions were made are indicated above each construct. HR was scored on a 0 (no HR) to 5 (strong HR) scale according to Slootweg et al. (2013) and Wang et al. (2015). Localization to the nucleus (N) or cytoplasm (C) is noted. + indicates visible accumulation and - indicates no visible accumulation. B, Total protein was extracted from agroinfiltrated leaves at $30 \mathrm{~h}$ postinfiltration, and anti-green fluorescent protein antibody was used to detect the expression of fused proteins. Equal loading of protein samples was shown by Ponceau S staining of Rubisco subunit (right, below). The

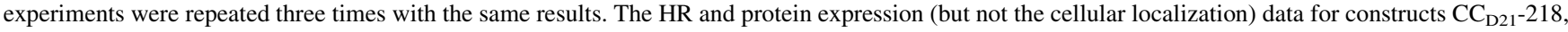
$\mathrm{CC}_{\mathrm{D} 21}-235, \mathrm{CC}_{\mathrm{D} 21}-260, \mathrm{CC}_{\mathrm{D} 21}-318$, and $\mathrm{CC}_{\mathrm{D} 21-370}$ have been previously reported (Wang et al 2015). 
barley MLA10, tobacco N, and rice Pb1, which are localized in both cytoplasmic and nuclear pools, are associated with transcription factors HvWRKY1/2 or HvMYB6, SPL6, and OsWRKY45, respectively (Chang et al. 2013; Inoue et al. 2013; Padmanabhan et al. 2013; Shen et al. 2007). Arabidopsis RPM1 and RPP5 associated with a transcriptional regulator, TIP49a (Holt et al. 2002). An unusual nuclear-localized TNL from Arabidopsis, RRS1-R, with a C-terminal WRKY DNA-binding domain, is thought to directly induce transcriptional reprogramming during defense (Caplan et al. 2008). Recently, it was reported that the type III effector PopP2 from Ralstonia solanacearum interacts with the WRKY domain of RRS1-R, suggesting the WRKY domain might work as a decoy (Cesari et al. 2014). The lipase-like EDS1 (enhanced disease susceptibility 1) protein is indispensible for the function of most TNL. Balanced cytoplasmic and nuclear distributions of EDS1 are required for a complete plant innate immunity conferred by the Arabidopsis TNL RPS4 (Bhattacharjee et al. 2011; García et al. 2010; Heidrich et al. 2011).

Transient expression of either Rp1-D21-NLS or Rp1-D21-NES did not induce HR, while the coexpression of both constructs induced a very weak or no response. We obtained essentially similar results with NLS and NES fusions to the $\mathrm{CC}_{\mathrm{D} 21}$ domain (Figs. 3 and 4). These results indicated that the separate distributions of the proteins in one or both the cytoplasm and nucleus were not sufficient to trigger strong HR and strongly implied that protein trafficking between cytoplasm and the nucleus was important for inducing HR. By reference to previous studies discussed above, it is reasonable to hypothesize that Rp1-D21 might become activated in the cytoplasm and, then, induce HR through the interaction with transcription factors in the nucleus.

It should be noted that we cannot definitively prove that the failure of Rp1-D21-NLS or Rp1-D21-NES to induce HR was due to their altered localization rather than to some nonspecific interference of these tags with the protein's function. However, we provide substantial circumstantial evidence that this is the case. First, we show that these tags change the protein distribution in the predicted way (Fig. 3). Second, the addition of nls or nes tags (that differ from NLS and NES by 1 and 3 aa, respectively) at the same place in the construct did not abolish HR induction (Fig. 3B and C). Third, this is a widely used method; previous studies have used the identical tags for investigating the defense response mediated by other NLR proteins, e.g., barley MLA, potato Rx, Arabidopsis RPM1, and SNC1 (Bai et al. 2012; Gao et al. 2011; Shen et al. 2007; Slootweg et al. 2010; Tameling et al. 2010; Zhu et al. 2010).

In this study we have identified the subcellular localization requirement for the activity of an autoactive NLR, Rp1-D21, its parental allele Rp1-dp2, and its autoactive subdomain $\mathrm{CC}_{21}$. Most importantly, we demonstrate that both nuclear and cytoplasmic distributions are required for activity of Rp1-D21 and $\mathrm{CC}_{21}$ and provide data that strongly implicate the importance of the movement between the two compartments in activity.

This work provides another example of the intriguing diversity of structural and localization patterns and activation requirements found among NLR R proteins (Table 1). In this case, we identify important differences even between two NLR that are $90 \%$ identical at the aa level. This diversity is found despite both apparent strong structural conservation and the fact that most of the characterized NLR are involved in HRmediated disease resistance. Each NLR protein is involved in a unique evolutionary arms race with its corresponding pathogen or effector and it is likely that the unique selection pressures exerted by each individual arms race have contributed to this remarkable functional diversity.

\section{MATERIALS AND METHODS}

Plant materials and growth conditions.

Wild-type $N$. benthamiana and the transgenic $N$. benthamiana harboring histone $2 \mathrm{~B}(\mathrm{H} 2 \mathrm{~B})$-TaqRFP were grown at $23^{\circ} \mathrm{C}$ with a cycle of $16 \mathrm{~h}$ of light and $8 \mathrm{~h}$ of dark.

\section{Plasmid construction.}

All primers used in this study are listed in Supplementary Table 1. Rp1-D, Rp1-dp2, Rp1-D21, and its different domains $\left(\mathrm{CC}_{\mathrm{D} 21}, \mathrm{NB}_{\mathrm{D} 21}, \mathrm{LRR}_{\mathrm{D} 21}, \mathrm{CC}-\mathrm{NB}_{\mathrm{D} 21}\right.$, and NB-LRR $\left.\mathrm{D}_{21}\right)$ were cloned into pENTR directional TOPO cloning vector (D-TOPO; Invitrogen), as described before (Wang et al. 2015). After sequencing, they were transferred into Gateway vectors by LR reactions: pGWB14 (with a $3 \times \mathrm{HA}$ epitope tag in the C-terminus) or pSITEII-N1-EGFP (with eGFP epitopic tag in the C-terminus) (Martin et al. 2009; Nakagawa et al. 2007). For constructs used for subcellular localization analysis, the NLS sequence (QPKKKRKVGG) and its mutant nls sequence (QPKKTRKVGG) and the NES sequence (NELALKLAGLDINK) and its mutant nes sequence (NELALKAAGADANK) were fused to the $\mathrm{C}$ terminus of Rp1-D21 or $\mathrm{CC}_{\mathrm{D} 21}$ by polymerase chain reaction (Bai et al. 2012; Wen et al. 1995). All genes were cloned into D-TOPO vector. After being verified by sequencing, they were constructed into pSITEII-N1-EGFP by Gateway LR reactions.

\section{Agrobacterium tumefaciens-mediated transient expression.}

Agrobacterium tumefaciens GV3101 (pMP90) transformed with different binary vector constructs was grown at $28^{\circ} \mathrm{C}$ overnight in $10 \mathrm{ml}$ L-broth medium supplemented with appropriate antibiotics. The bacteria were collected at 4,000 $\times g$ by centrifugation and were resuspended in $2 \mathrm{ml}$ of resuspension buffer $\left(10 \mathrm{mM}\right.$ MES, pH5.6, $10 \mathrm{mM} \mathrm{MgCl}_{2}$, and $200 \mu \mathrm{M}$ acetosyringone). The final concentration of the bacteria was diluted to the optical density at $600 \mathrm{~nm}\left(\mathrm{OD}_{600}\right)$ of 0.5 , using the same resuspension buffer. To prevent the onset of posttranscriptional gene silencing and to improve the efficiency of transient expression, an Agrobacterium strain carrying a cassette directing the expression of the silencing suppressor p19 protein was included at $\mathrm{OD}_{600}$ of 0.2 for all transformations (Voinnet et al. 2003). The solution was left at room temperature for $3 \mathrm{~h}$ on the bench, before infiltration into the abaxial side of $N$. benthamiana leaves. After infiltration, plants were incubated at room temperature with $16 \mathrm{~h}$ of light and $8 \mathrm{~h}$ of dark. At least 15 individual leaves were infiltrated for each construct, and each experiment was repeated at least three times.

\section{Ion leakage measurement.}

Ion leakage was measured according to previous reports with minor modifications (Booker et al. 2012). At least five leaf discs $(1.2 \mathrm{~cm}$ diameter) from different plants were collected and were put in $4 \mathrm{ml}$ of sterile $\mathrm{H}_{2} \mathrm{O}$ in a 15 -ml polypropylene tube. The samples were shaken for $3 \mathrm{~h}$ at room temperature, and the conductivity $(\mathrm{C} 1)$ was measured by a conductivity meter (Model 4403; Markson Science, Inc.). Subsequently, samples were boiled for $15 \mathrm{~min}$, and the total conductivity (C2) was measured again. The ion leakage was calculated as $\mathrm{C} 1 / \mathrm{C} 2$ ratio.

\section{Analysis of protein levels by Western blot.}

Three leaf discs $(1.2 \mathrm{~cm}$ diameter) from different single plants were collected at $30 \mathrm{~h}$ postinfiltration (hpi). The samples were ground with prechilled plastic pestles in liquid nitrogen, and total protein was extracted in $150 \mu$ l of extraction buffer (20 mM Tris $\cdot \mathrm{HCl}[\mathrm{pH} 8.0], 150 \mathrm{mM} \mathrm{NaCl}, 1 \mathrm{mM}$ EDTA [pH 8.0], $1 \%$ Triton $X-100,0.1 \%$ sodium dodecyl sulfate [SDS], $10 \mathrm{mM}$ dithiothreitol [DTT], $40 \mu \mathrm{M} \mathrm{MG132}$, and $1 \times$ plant 
protein protease inhibitor mixture [Sigma-Aldrich]). Samples were centrifuged at $14,000 \times g$ for $15 \mathrm{~min}$ at $4^{\circ} \mathrm{C}$, and $12 \mu \mathrm{l}$ of supernatants were mixed with $2 \times$ Laemmli buffer and were loaded for SDS-polyacrylamide gel electrophoresis (PAGE). Proteins were transferred to nitrocellulose membrane (Fisher) and were analyzed by Western blot. HA detection was performed using a 1:350 dilution of anti-HA-HRP (horseradish peroxidase) (Roche). GFP detection was performed using a 1:8,000 dilution of primary mouse monoclonal anti-GFP (Abcam), followed by hybridization with a 1:15,000 dilution of antimouse-HRP second antibody (Sigma). The PM marker anti- $\mathrm{H}^{+}$-ATPase (Agrisera) and the soluble marker anti-APX (Agrisera) were used at a 1:8,000 dilution, followed by hybridization with a 1:15,000 dilution of antirabbit-HRP second antibody (GenScript). The HRP signal was detected by ECL substrate kit (Supersignal West Femto Chemiluminescent substrate; Thermo Scientific).

\section{Membrane fractionation.}

About 2-g samples of leaf tissue were ground in prechilled mortars with liquid nitrogen, and then, were homogenized with $4 \mathrm{ml}$ of lysis buffer (50 mM Tris $\cdot \mathrm{HCl}$ [pH 7.5], $0.33 \mathrm{M}$ sucrose, $5 \mathrm{mM}$ EDTA [pH 8.0], $5 \mathrm{mM}$ DTT, $40 \mu \mathrm{M}$ MG132, and 1× plant protein protease inhibitor mixture [Sigma-Aldrich]). The lysate was centrifuged at $4,000 \times g$ for $15 \mathrm{~min}$ and was filtered with two-layer Miracloth. Keeping $100 \mu \mathrm{l}$ of supernatant as T1 (total protein), the remaining supernatant was fractioned into a soluble fraction (S1) and a microsomal membrane fraction (M1) by ultracentrifugation at $100,000 \times g$ for $1 \mathrm{~h}$. M1 was gently washed twice with the lysis buffer and was then resuspended in $300 \mu$ of lysis buffer. Samples were mixed with $2 \times$ Laemmli buffer and were loaded for SDS-PAGE. Proteins were transferred to nitrocellulose membrane (Fisher) and were analyzed by immunoblotting.

\section{Confocal microscopy.}

The abaxial sides of $N$. benthaminana leaves infiltrated by agrobacteria were cut for observation, at 30 hpi for constructs inducing HR or $48 \mathrm{hpi}$ for constructs without inducing HR, by a confocal microscope (LSM 710, Carl Zeiss). eGFP fluorescence was excited at $488 \mathrm{~nm}$ and was observed between 495 and $550 \mathrm{~nm}$. CFP fluorescence was excited at $458 \mathrm{~nm}$ and was observed between 462 and $520 \mathrm{~nm}$. TaqRFP was excited at $561 \mathrm{~nm}$ and was observed between 580 and $675 \mathrm{~nm}$. For nuclear staining, 4',6-diamidino-2-phenylindole (DAPI) $(10 \mu \mathrm{g} / \mathrm{ml})$ was infiltrated into the leaves $2 \mathrm{~h}$ before confocal observation. DAPI fluorescence was excited at $375 \mathrm{~nm}$ and was observed between 385 and $470 \mathrm{~nm}$.

\section{ACKNOWLEDGMENTS}

We thank J. Dangl for providing the bacterial strain carrying AtPLC2: CFP and for helpful discussion. We thank M.1 Goodin for providing the vectors of pSITEII-N1-EGFP, pSITEII-N1-TagRFP, and the transgenic $N$. benthamiana seeds harboring H2B-TaqRFP. We are grateful to S. Sermons for help with obtaining reagents, M. Rojas-Pierce for help with membrane fractionation, E. Johannes for help with microscopy observation. The Genomic Sciences Laboratory at North Carolina State University provided DNA sequencing services. We also thank Y. He and F. EI Kasmi for critical reading of the manuscript and G. Johal, M. Nishimura, J. Alonso, A. Stepanova, and R. G. Franks for helpful discussion. This work was supported by National Science Foundation (award number 0822495) and the U.S. Department of Agriculture-Agricultural Research Service.

\section{LITERATURE CITED}

Axtell, M. J., and Staskawicz, B. J. 2003. Initiation of RPS2-specified disease resistance in Arabidopsis is coupled to the AvrRpt2-directed elimination of RIN4. Cell 112:369-377.
Bai, S., Liu, J., Chang, C., Zhang, L., Maekawa, T., Wang, Q., Xiao, W., Liu, Y., Chai, J., Takken, F. L., Schulze-Lefert, P., and Shen, Q. H. 2012. Structure-function analysis of barley NLR immune receptor MLA10 reveals its cell compartment specific activity in cell death and disease resistance. PLoS Pathog. 8:e1002752.

Belkhadir, Y., Subramaniam, R., and Dangl, J. L. 2004. Plant disease resistance protein signaling: NBS-LRR proteins and their partners. Curr Opin. Plant Biol. 7:391-399.

Bent, A. F., and Mackey, D. 2007. Elicitors, effectors, and $R$ genes: The new paradigm and a lifetime supply of questions. Annu. Rev. Phytopathol. 45:399-436.

Bernoux, M., Ve, T., Williams, S., Warren, C., Hatters, D., Valkov, E., Zhang, X., Ellis, J. G., Kobe, B., and Dodds, P. N. 2011. Structural and functional analysis of a plant resistance protein TIR domain reveals interfaces for self-association, signaling, and autoregulation. Cell Host Microbe 9:200-211.

Bhattacharjee, S., Halane, M. K., Kim, S. H., and Gassmann, W. 2011. Pathogen effectors target Arabidopsis EDS1 and alter its interactions with immune regulators. Science 334:1405-1408.

Booker, F., Burkey, K., Morgan, P., Fiscus, E., and Jones, A. 2012. Minimal influence of G-protein null mutations on ozone-induced changes in gene expression, foliar injury, gas exchange and peroxidase activity in Arabidopsis thaliana L. Plant Cell Environ. 35:668-681.

Burch-Smith, T. M., Schiff, M., Caplan, J. L., Tsao, J., Czymmek, K., and Dinesh-Kumar, S. P. 2007. A novel role for the TIR domain in association with pathogen-derived elicitors. PLoS Biol. 5:e68.

Cannon, S. B., Zhu, H., Baumgarten, A. M., Spangler, R., May, G., Cook, D. R., and Young, N. D. 2002. Diversity, distribution, and ancient taxonomic relationships within the TIR and non-TIR NBS-LRR resistance gene subfamilies. J. Mol. Evol. 54:548-562.

Caplan, J., Padmanabhan, M., and Dinesh-Kumar, S. P. 2008. Plant NBLRR immune receptors: From recognition to transcriptional reprogramming. Cell Host Microbe 3:126-135.

Cesari, S., Bernoux, M., Moncuquet, P., Kroj, T., and Dodds, P. N. 2014. A novel conserved mechanism for plant NLR protein pairs: The "integrated decoy" hypothesis. Front. Plant Sci. 5:606.

Chaikam, V., Negeri, A., Dhawan, R., Puchaka, B., Ji, J., Chintamanani, S., Gachomo, E. W., Zillmer, A., Doran, T., Weil, C., Balint-Kurti, P., and Johal, G. 2011. Use of mutant-assisted gene identification and characterization (MAGIC) to identify novel genetic loci that modify the maize hypersensitive response. Theor. Appl. Genet. 123 985-997.

Chang, C., Yu, D., Jiao, J., Jing, S., Schulze-Lefert, P., and Shen, Q. H. 2013. Barley MLA immune receptors directly interfere with antagonistically acting transcription factors to initiate disease resistance signaling Plant Cell 25:1158-1173.

Cheng, Y. T., Germain, H., Wiermer, M., Bi, D., Xu, F., García, A. V., Wirthmueller, L., Després, C., Parker, J. E., Zhang, Y., and Li, X. 2009 Nuclear pore complex component MOS7/Nup88 is required for innate immunity and nuclear accumulation of defense regulators in Arabidopsis. Plant Cell 21:2503-2516.

Chintamanani, S., Hulbert, S. H., Johal, G. S., and Balint-Kurti, P. J. 2010. Identification of a maize locus that modulates the hypersensitive defense response, using mutant-assisted gene identification and characterization. Genetics 184:813-825.

Collier, S. M., Hamel, L. P., and Moffett, P. 2011. Cell death mediated by the N-terminal domains of a unique and highly conserved class of NBLRR protein. Mol. Plant Microbe Interact. 24:918-931.

Collins, N., Drake, J., Ayliffe, M., Sun, Q., Ellis, J., Hulbert, S., and Pryor, T. 1999. Molecular characterization of the maize $R p 1-D$ rust resistance haplotype and its mutants. Plant Cell 11:1365-1376.

Dangl, J. L., and Jones, J. D. 2001. Plant pathogens and integrated defence responses to infection. Nature 411:826-833.

Day, B., Dahlbeck, D., Huang, J., Chisholm, S. T., Li, D., and Staskawicz, B. J. 2005. Molecular basis for the RIN4 negative regulation of RPS2 disease resistance. Plant Cell 17:1292-1305.

Engelhardt, S., Boevink, P. C., Armstrong, M. R., Ramos, M. B., Hein, I., and Birch, P. R. 2012. Relocalization of late blight resistance protein R3a to endosomal compartments is associated with effector recognition and required for the immune response. Plant Cell 24:5142-5158.

Gao, Z., Chung, E. H., Eitas, T. K., and Dangl, J. L. 2011. Plant intracellular innate immune receptor Resistance to Pseudomonas syringae pv maculicola 1 (RPM1) is activated at, and functions on, the plasma membrane. Proc. Natl. Acad. Sci. U.S.A. 108:7619-7624.

García, A. V., Blanvillain-Baufumé, S., Huibers, R. P., Wiermer, M., Li, G., Gobbato, E., Rietz, S., and Parker, J. E. 2010. Balanced nuclear and cytoplasmic activities of EDS1 are required for a complete plant innate immune response. PLoS Pathog. 6:e1000970. 
Heidrich, K., Wirthmueller, L., Tasset, C., Pouzet, C., Deslandes, L., and Parker, J. E. 2011. Arabidopsis EDS1 connects pathogen effector recognition to cell compartment-specific immune responses. Science 334:1401-1404.

Hirayama, T., Mitsukawa, N., Shibata, D., and Shinozaki, K. 1997. AtPLC2, a gene encoding phosphoinositide-specific phospholipase $\mathrm{C}$, is constitutively expressed in vegetative and floral tissues in Arabidopsis thaliana. Plant Mol. Biol. 34:175-180.

Holt, B. F., 3rd, Boyes, D. C., Ellerström, M., Siefers, N., Wiig, A., Kauffman, S., Grant, M. R., and Dangl, J. L. 2002. An evolutionarily conserved mediator of plant disease resistance gene function is required for normal Arabidopsis development. Dev. Cell 2:807-817.

Hoser, R., Zurczak, M., Lichocka, M., Zuzga, S., Dadlez, M., Samuel, M. A., Ellis, B. E., Stuttmann, J., Parker, J. E., Hennig, J., and Krzymowska, M. 2013. Nucleocytoplasmic partitioning of tobacco N receptor is modulated by SGT1. New Phytol. 200:158-171.

Hu, G., Richter, T. E., Hulbert, S. H., and Pryor, T. 1996. Disease lesion mimicry caused by mutations in the rust resistance gene rp1. Plant Cell 8:1367-1376.

Hulbert, S. H. 1997. Structure and evolution of the rpl complex conferring rust resistance in maize. Annu. Rev. Phytopathol. 35:293-310.

Inoue, H., Hayashi, N., Matsushita, A., Xinqiong, L., Nakayama, A., Sugano, S., Jiang, C. J., and Takatsuji, H. 2013. Blast resistance of CCNB-LRR protein $\mathrm{Pb} 1$ is mediated by WRKY45 through protein-protein interaction. Proc. Natl. Acad. Sci. U.S.A. 110:9577-9582.

Jones, J. D., and Dangl, J. L. 2006. The plant immune system. Nature 444: 323-329.

Kawano, Y., Akamatsu, A., Hayashi, K., Housen, Y., Okuda, J., Yao, A., Nakashima, A., Takahashi, H., Yoshida, H., Wong, H. L., Kawasaki, T. and Shimamoto, K. 2010. Activation of a Rac GTPase by the NLR family disease resistance protein Pit plays a critical role in rice innate immunity. Cell Host Microbe 7:362-375

Kawano, Y., Fujiwara, T., Yao, A., Housen, Y., Hayashi, K., and Shimamoto, K. 2014. Palmitoylation-dependent membrane localization of the rice resistance protein pit is critical for the activation of the small GTPase OsRac1. J. Biol. Chem. 289:19079-19088.

Maekawa, T., Cheng, W., Spiridon, L. N., Töller, A., Lukasik, E., Saijo, Y., Liu, P., Shen, Q. H., Micluta, M. A., Somssich, I. E., Takken, F. L., Petrescu, A. J., Chai, J., and Schulze-Lefert, P. 2011. Coiled-coil domain-dependent homodimerization of intracellular barley immune receptors defines a minimal functional module for triggering cell death Cell Host Microbe 9:187-199.

Martin, K., Kopperud, K., Chakrabarty, R., Banerjee, R., Brooks, R., and Goodin, M. M. 2009. Transient expression in Nicotiana benthamiana fluorescent marker lines provides enhanced definition of protein localization, movement and interactions in planta. Plant J. 59:150-162.

Mestre, P., and Baulcombe, D. C. 2006. Elicitor-mediated oligomerization of the tobacco N disease resistance protein. Plant Cell 18:491-501.

Meyers, B. C., Dickerman, A. W., Michelmore, R. W., Sivaramakrishnan, S., Sobral, B. W., and Young, N. D. 1999. Plant disease resistance genes encode members of an ancient and diverse protein family within the nucleotide-binding superfamily. Plant J. 20:317-332.

Nakagawa, T., Kurose, T., Hino, T., Tanaka, K., Kawamukai, M., Niwa, Y. Toyooka, K., Matsuoka, K., Jinbo, T., and Kimura, T. 2007. Develop-

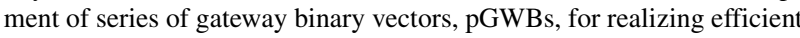
construction of fusion genes for plant transformation. J. Biosci. Bioeng. 104:34-41.

Negeri, A., Wang, G.-F., Benavente, L., Kibiti, C. M., Chaikam, V., Johal, G., and Balint-Kurti, P. 2013. Characterization of temperature and light effects on the defense response phenotypes associated with the maize Rp1-D21 autoactive resistance gene. BMC Plant Biol. 13:106.

Padmanabhan, M. S., Ma, S., Burch-Smith, T. M., Czymmek, K., Huijser, P., and Dinesh-Kumar, S. P. 2013. Novel positive regulatory role for the SPL6 transcription factor in the N TIR-NB-LRR receptor-mediated plant innate immunity. PLoS Pathog. 9:e1003235.

Palma, K., Zhang, Y., and Li, X. 2005. An importin alpha homolog, MOS6, plays an important role in plant innate immunity. Curr. Biol. 15: 1129-1135.

Qi, D., DeYoung, B. J., and Innes, R. W. 2012. Structure-function analysis of the coiled-coil and leucine-rich repeat domains of the RPS5 disease resistance protein. Plant Physiol. 158:1819-1832.
Rairdan, G. J., Collier, S. M., Sacco, M. A., Baldwin, T. T., Boettrich, T., and Moffett, P. 2008. The coiled-coil and nucleotide binding domains of the potato $\mathrm{Rx}$ disease resistance protein function in pathogen recognition and signaling. Plant Cell 20:739-751.

Rairdan, G. J., and Moffett, P. 2006. Distinct domains in the ARC region of the potato resistance protein Rx mediate LRR binding and inhibition of activation. Plant Cell 18:2082-2093.

Shen, Q. H., Saijo, Y., Mauch, S., Biskup, C., Bieri, S., Keller, B., Seki, H., Ulker, B., Somssich, I. E., and Schulze-Lefert, P. 2007. Nuclear activity of MLA immune receptors links isolate-specific and basal diseaseresistance responses. Science 315:1098-1103.

Slootweg, E., Roosien, J., Spiridon, L. N., Petrescu, A. J., Tameling, W., Joosten, M., Pomp, R., van Schaik, C., Dees, R., Borst, J. W., Smant, G., Schots, A., Bakker, J., and Goverse, A. 2010. Nucleocytoplasmic distribution is required for activation of resistance by the potato NB-LRR receptor Rx 1 and is balanced by its functional domains. Plant Cell 22: 4195-4215.

Slootweg, E. J., Spiridon, L. N., Roosien, J., Butterbach, P., Pomp, R. Westerhof, L., Wilbers, R., Bakker, E., Bakker, J., Petrescu, A. J., Smant, G., and Goverse, A. 2013. Structural determinants at the interface of the ARC2 and leucine-rich repeat domains control the activation of the plant immune receptors Rx1 and Gpa2. Plant Physiol. 162:1510-1528.

Smith, S. M., Steinau, M., Trick, H. N., and Hulbert, S. H. 2010 Recombinant Rpl genes confer necrotic or nonspecific resistance phenotypes. Mol. Genet. Genomics 283:591-602.

Sudupak, M. A., Bennetzen, J. L., and Hulbert, S. H. 1993. Unequal exchange and meiotic instability of disease-resistance genes in the Rp1 region of maize. Genetics 133:119-125.

Takemoto, D., Rafiqi, M., Hurley, U., Lawrence, G. J., Bernoux, M., Hardham, A. R., Ellis, J. G., Dodds, P. N., and Jones, D. A. 2012 $\mathrm{N}$-terminal motifs in some plant disease resistance proteins function in membrane attachment and contribute to disease resistance. Mol. Plant Microbe Interact. 25:379-392.

Takken, F. L., and Tameling, W. I. 2009. To nibble at plant resistance proteins. Science 324:744-746

Tameling, W. I., and Baulcombe, D. C. 2007. Physical association of the NBLRR resistance protein $\mathrm{Rx}$ with a Ran GTPase-activating protein is required for extreme resistance to Potato virus X. Plant Cell 19:1682-1694.

Tameling, W. I., Nooijen, C., Ludwig, N., Boter, M., Slootweg, E., Goverse, A., Shirasu, K., and Joosten, M. H. 2010. RanGAP2 mediates nucleocytoplasmic partitioning of the NB-LRR immune receptor Rx in the Solanaceae, thereby dictating Rx function. Plant Cell 22:4176-4194.

Tao, Y., Yuan, F., Leister, R. T., Ausubel, F. M., and Katagiri, F. 2000. Mutational analysis of the Arabidopsis nucleotide binding site-leucinerich repeat resistance gene RPS2. Plant Cell 12:2541-2554.

Voinnet, O., Rivas, S., Mestre, P., and Baulcombe, D. 2003. An enhanced transient expression system in plants based on suppression of gene silencing by the p19 protein of Tomato bushy stunt virus. Plant J. 33:949-956.

Wang, G.-F., Ji, J., El-Kasmi, F., Dangl, J. L., Johal, G., and Balint-Kurti, P. J. 2015. Molecular and functional analyses of a maize autoactive NBLRR protein identify precise structural requirements for activity. PLoS Pathog. 11:e1004674.

Wen, W., Meinkoth, J. L., Tsien, R. Y., and Taylor, S. S. 1995. Identification of a signal for rapid export of proteins from the nucleus. Cell 82: 463-473.

Williams, S. J., Sohn, K. H., Wan, L., Bernoux, M., Sarris, P. F., Segonzac, C., Ve, T., Ma, Y., Saucet, S. B., Ericsson, D. J., Casey, L. W., Lonhienne T., Winzor, D. J., Zhang, X., Coerdt, A., Parker, J. E., Dodds, P. N., Kobe, B., and Jones, J. D. 2014. Structural basis for assembly and function of a heterodimeric plant immune receptor. Science 344:299-303.

Wirthmueller, L., Zhang, Y., Jones, J. D., and Parker, J. E. 2007. Nuclear accumulation of the Arabidopsis immune receptor RPS4 is necessary for triggering EDS1-dependent defense. Curr. Biol. 17:2023-2029.

Zhang, Y., Dorey, S., Swiderski, M., and Jones, J. D. 2004. Expression of RPS4 in tobacco induces an AvrRps4-independent HR that requires EDS1, SGT1 and HSP90. Plant J. 40:213-224.

Zhang, Y., and Li, X. 2005. A putative nucleoporin 96 Is required for both basal defense and constitutive resistance responses mediated by suppressor of npr1-1,constitutive 1. Plant Cell 17:1306-1316.

Zhu, Y., Qian, W., and Hua, J. 2010. Temperature modulates plant defense responses through NB-LRR proteins. PLoS Pathog. 6:e1000844. 